\title{
Analysis of the Gene Sequences of the Insulin Receptor and the Insulin-sensitive Glucose Transporter (GLUT-4) in Patients with Common-Type Non-Insulin-dependent Diabetes Mellitus
}

\author{
J. Kusari, U. S. Verma, J. B. Buse," R. R. Henry, and J. M. Olefsky \\ Department of Medicine, University of California, San Diego, La Jolla, California 92093; Department of Veterans Affairs, \\ Veterans Administration Medical Center, San Diego, California 92161; and *Department of Medicine, \\ University of Chicago, Chicago, Illinois 60637
}

\begin{abstract}
Insulin resistance is a common feature of non-insulin-dependent diabetes mellitus (NIDDM) and "diabetes susceptibility genes" may be involved in this abnormality. Two potential candidate genes are the insulin receptor (IR) and the insulin-sensitive glucose transporter (GLUT-4). To elucidate whether structural defects in the IR and/or GLUT -4 could be a primary cause of insulin resistance in NIDDM, we have sequenced the entire coding region of the GLUT -4 gene from DNA of six NIDDM patients. Since binding properties of the IRs from NIDDM subjects are normal, we also analyzed the sequence of exons 16-22 (encoding the entire cytoplasmic domain of the IR) of the IR gene from the same six patients. When compared with the normal IR sequence, no difference was found in the predicted amino acid sequence of the IR cytoplasmic domain derived from the NIDDM patients. Sequence analysis of the GLUT -4 gene revealed that one patient was heterozygous for a mutation in which isoleucine (ATC) was substituted for valine (GTC) at position 383. Consequently, the GLUT-4 sequence at position 383 was determined in 24 additional NIDDM patients and 30 nondiabetic controls and all showed only the normal sequence. From these studies, we conclude that the insulin resistance seen in the great majority of subjects with the common form of NIDDM is not due to genetic variation in the coding sequence of the IR $\beta$ subunit, nor to any single mutation in the GLUT-4 gene. Possibly, a subpopulation of NIDDM patients exists displaying variation in the GLUT-4 gene. ( J. Clin. Invest. 1991. 88:1323-1330.) Key words: insulin receptor gene • insulin resistance - insulin-sensitive glucose transporter (GLUT-4) gene • non-insulin-dependent diabetes mellitus • polymorphism • sequencing
\end{abstract}

\section{Introduction}

Although non-insulin-dependent diabetes mellitus (NIDDM) ${ }^{1}$ is a heterogeneous pathophysiologic disorder, insulin resis-

Address reprint requests to Dr. Kusari, V-111G, Veterans Administration Medical Center, 3350 La Jolla Village Drive, San Diego, CA 92161.

Received for publication 6 February 1991 and in revised form 13 May 1991

1. Abbreviations used in this paper: NIDDM, non-insulin-dependent diabetes mellitus; PCR, polymerase chain reaction.

The Journal of Clinical Investigation, Inc.

Volume 88, October 1991, 1323-1330 tance is a characteristic feature in essentially all subjects with established hyperglycemia (1). Furthermore, recent evidence indicates that in high-risk populations, individuals destined to develop NIDDM are insulin resistant before the onset of clinically apparent hyperglycemia $(2,3)$. In the prediabetic state, increased insulin secretion compensates for the insulin resistance, but when this compensating mechanism fails, hyperglycemia ensues. This suggests that insulin resistance is a primary defect of etiologic importance in the pathogenesis of this disease. The cellular basis for this insulin resistance has received considerable attention (4), and most studies have indicated that postbinding defects are the predominant cause of the decrease in insulin action $(5,6)$. Thus, insulin receptor signaling is impaired in NIDDM and decreased insulin receptor autophosphorylation and tyrosine kinase activity has been reported in fat $(7,8)$, liver $(9)$, and skeletal muscle $(10)$, as well as other tissues (11). In addition, a decrease in insulin-stimulated glucose transport activity has been consistently observed in skeletal muscle and adipocytes from $\operatorname{NIDDM}$ subjects $(4,12)$. Since the insulin-sensitive glucose transporter (GLUT-4) is responsible for the preponderance of insulin-mediated glucose uptake in these tissues $(13,14)$, the reported decrease in glucose transport activity must involve impaired GLUT-4 function. Interestingly, although the adipocyte glucose transporter number is decreased in NIDDM (4), recent studies have reported normal total skeletal muscle GLUT-4 levels (15). Since skeletal muscle is the major site of in vivo glucose disposal, this indicates that impaired recruitment of GLUT-4 to the cell surface or decreased GLUT-4 intrinsic activity accounts for the component of insulin resistance owing to the glucose transport defect in NIDDM.

NIDDM has a strong genetic component $(16,17)$, raising the possibility that insulin resistance is inherited in this disorder. Given that defects in both insulin receptor and GLUT-4 functions have been identified in this condition, it seemed reasonable to speculate that a molecular alteration in the genes encoding one or both of these proteins might exist. To assess this question, we have sequenced the exons comprising the entire GLUT-4 coding sequence in six NIDDM subjects, whose clinical and metabolic characteristics were typical for type II diabetic subjects. In these same patients we have sequenced the exons (16-22) that encode the cytoplasmic domain of the insulin receptor (18). We chose this latter approach, rather than analyzing the entire receptor gene, because the functions of the cytoplasmic domain (signaling and kinase activity) are impaired in NIDDM (4), whereas properties of the ectodomain (binding) are normal $(10,19,20)$. 


\section{Methods}

Chemicals. The following were purchased: avian myeloblastosis virus reverse transcriptase, T7 RNA polymerase from Promega Corp., Madison, WI; Taq polymerase from Perkin-Elmer Cetus, Norwalk, CT; T4 polynucleotide kinase, deoxynucleotides, nick-translation kit from Bethesda Research Laboratories, Gaithersburg, MD; dideoxynucleotides, Sephadex G-50 from Pharmacia, Inc., Piscataway, NJ; Centricon 100 from Amicon Corp., Danvers, MA; Sequenase from United States Biochemical Corp., Cleveland, $\mathrm{OH}$; perfect match from Strategene Inc., La Jolla, CA; $\left.\left[\gamma^{-32} \mathrm{P}\right] \mathrm{ATP}(6,000 \mathrm{Ci} / \mathrm{mmol}),{ }^{32} \mathrm{P}\right] \mathrm{dCTP}(3,000$ $\mathrm{Ci} / \mathrm{mmol}$ ) from Dupont New England Nuclear, Boston, MA; all other chemicals used were primarily from Sigma Chemical Co., St. Louis, MO.

Subjects. The clinical and metabolic characteristics of the six NIDDM subjects are presented in Table I. Subject 2 is Mexican American and the other five subjects are Caucasian. All six subjects had unequivocal fasting hyperglycemia and displayed insulin resistance as assessed by the euglycemic glucose clamp technique. Based on fasting glucose and insulin levels, body mass index, age, and clinical characteristics they represent "typical" NIDDM subjects. An additional group of 24 NIDDM patients and 30 nondiabetic controls was used in the allele-specific polymerase chain reaction (PCR) screening studies as described below. All nondiabetics were confirmed as normal on the basis of standard 75-g oral glucose tolerance tests and each of the additional 24 NIDDM subjects had fasting plasma glucose levels $>9.7$ $\mathrm{mmol} /$ liter.

Preparation of genomic DNA from the patient's blood. Genomic DNA was isolated from peripheral blood according to standard procedures (21).

Enzymatic amplification of genomic DNA. Five different sets of primers (Table II) were used to amplify 11 exons and adjacent introns of the GLUT-4 gene by PCR (22). By using sets of primers as described by Seino et al. (23), the regions representing exons 16-22 of the insulin receptor gene were amplified using standard conditions of PCR. Briefly, each reaction was performed in a volume of $25 \mu \mathrm{l}$ containing 50 $\mathrm{mM} \mathrm{KCl}, 10 \mathrm{mM}$ Tris-Cl (pH 8.3), $1 \mathrm{mM} \mathrm{MgCl}, 100 \mu \mathrm{g} / \mathrm{ml}$ gelatin; $100 \mu \mathrm{M}$ each of dATP, dGTP, dCTP, and dTTP; $1 \mu \mathrm{M}$ of each oligonucleotide primer, $0.25 \mu \mathrm{g}$ of Hind III-digested genomic DNA; $1.25 \mathrm{U}$ Taq DNA polymerase; and $1 \mathrm{U}$ perfect match. After initial denaturation at $94^{\circ} \mathrm{C}$ for $10 \mathrm{~min}$, the samples were subjected to 40 cycles of amplification with an automated thermal cycler (Ericomp, Inc., San Diego, CA); annealing at $48-55^{\circ} \mathrm{C}$ (depending on the melting temperature of the primer) for $2 \mathrm{~min}$, extension at $72^{\circ} \mathrm{C}$ for $3 \mathrm{~min}$ and denaturation at $94^{\circ} \mathrm{C}$ for $1 \mathrm{~min}$. The upstream oligonucleotide of each set of primers contained a $\mathrm{T} 7$ phage promoter sequence at its $5^{\prime}$ end for direct sequence analysis by avian myeloblastosis virus reverse transcriptase as described (24).

Direct sequence analysis using single-stranded DNA as a template. In some instances, it was very difficult to analyze the nucleotide sequence of certain regions of the amplified DNA by reverse transcriptase. These regions include nucleotides 3529-3543 (exon 2), 37593777 (exon 3), 4272-4386 (exon 4b), and 5210-5234 (exon 7) of the
Table I. Clinical and Metabolic Characteristics of Subjects with NIDDM

\begin{tabular}{ccccccc}
\hline $\begin{array}{c}\text { Subject } \\
\text { No. }\end{array}$ & Age & Sex & $\begin{array}{c}\text { Body mass } \\
\text { index }\end{array}$ & $\begin{array}{l}\text { Fasting } \\
\text { glucose }\end{array}$ & $\begin{array}{l}\text { Fasting } \\
\text { insulin }\end{array}$ & $\begin{array}{c}\text { Glucose } \\
\text { disposal rate* }\end{array}$ \\
\hline & $y r$ & & $k g / M$ & mmol/liter & pmol/liter & mg/kg per min \\
1 & 52 & M & 40.6 & 15.0 & 143.5 & 6.30 \\
2 & 63 & M & 23.0 & 14.1 & 50.2 & ND \\
3 & 57 & F & 29.7 & 13.8 & 287.0 & 4.58 \\
4 & 67 & F & 28.8 & 17.3 & 71.7 & 4.53 \\
5 & 55 & F & 28.8 & 15.7 & 50.2 & 7.42 \\
6 & 67 & M & 26.3 & 17.6 & 64.6 & 5.54 \\
& & & & & & \\
\hline
\end{tabular}

ND, not determined.

* These values represent the steady-state glucose disposal rates during glucose clamp studies at an insulin infusion rate of $300 \mathrm{mU} / \mathrm{M}^{2}$ per min. The mean $( \pm \mathrm{SE})$ normal glucose disposal rate in our laboratory is $11.5 \pm 1.3 \mathrm{mg} / \mathrm{kg}$ per min and in NIDDM patients is $5.2 \pm 0.7 \mathrm{mg} / \mathrm{kg}$ per min.

GLUT-4 gene and nucleotides 12733-12932 of the insulin receptor exon 22 (23). In these cases, the sequence was determined by sequenase using single-stranded DNA as the template (25). Briefly, singlestranded DNA was synthesized according to the protocol described above for the first PCR (23), except for three changes. First, to amplify one strand of DNA selectively, only one of the two oligonucleotide primers (either the upstream or the downstream primer) was included. Secondly, amplified DNA (5 ng) synthesized in the first PCR was used as template. Finally, the second PCR reaction was carried out in a $100-\mu \mathrm{l}$ volume instead of $25 \mu \mathrm{l} .5 \mu \mathrm{l}$ of the second PCR product was run on a $1.5 \%$ agarose gel to document the size of the amplified product to be sequenced. Subsequently, the rest of the amplified DNA solution was extracted with an equal volume of chloroform. Single-stranded DNA was separated from the oligonucleotides and deoxynucleotide triphosphates by precipitation with ammonium chloride and isopropanol (25) followed by filtration through a Centricon 100 membrane according to the manufacturer's instruction (Amicon Corp.). The retentate $(45 \mu \mathrm{l})$ was dried in a concentrator (Speed Vac) and dissolved in $5 \mu \mathrm{l}$ of water immediately before use in the DNA sequencing reaction.

End-labeling of the sequencing primer $(40 \mathrm{pmol})$ was performed according to standard procedures (21). The ${ }^{32} \mathrm{P}$-labeled oligonucleotides were purified by chromatography through Sephadex G-50 (21). The eluant $(100 \mu \mathrm{l})$ was dried in a concentrator (Speed Vac, Savant Instruments Inc., Farmingdale, NY) and dissolved in $4.8 \mu \mathrm{l}$ of sterile water. Sequencing reactions using Sequenase were carried out according to the protocol used by Kadowaki et al. (26).

Allele-specific PCR amplification. For amplification of specific alleles by PCR, we used the method described by Sarkar et al. (27). The sets of primers used for amplification of either the normal or mutant GLUT-4 gene alleles are as follows:
Normal allele

A $\left\{\begin{array}{l}5^{\prime}-5843 \text { AGAATGCCAGTCAAGGGCC } \\ 5^{\prime 6037} \text { AGA1 }-3^{\prime}\end{array}\right.$
Mutant allele

$A^{\prime}\left\{\begin{array}{l}5^{\prime}-5843 \text { AGAATGCCAGTCAAGGGCC } \\ 5^{\prime}-{ }^{5861} \text { AGATGGCCACAATGGAGAT } \\ { }^{6019}-3^{\prime}\end{array}\right.$ 
Table II. Oligonucleotide Primers for Amplification of Human GLUT-4 Exons by the Polymerase Chain Reaction

\begin{tabular}{|c|c|c|c|c|}
\hline $\begin{array}{l}\text { Fragment } \\
\text { No. }\end{array}$ & Upstream primer & Downstream primer & Exon & $\begin{array}{c}\text { Size of PCR } \\
\text { fragment }\end{array}$ \\
\hline & & & & $b p$ \\
\hline A & $\begin{array}{l}\text { 5'-GAGACTCCAGGATCGGTTC } \\
(2162-80)\end{array}$ & $\begin{array}{c}\text { 5'-CTGCGCCTGCGCAGGAACC } \\
(2344-62)\end{array}$ & 1 & 224 \\
\hline B & $\begin{array}{c}\text { 5'-GGTTCCATGTGACATGCTG } \\
(3493-3511)\end{array}$ & $\begin{array}{c}\text { 5'-AAGCCCACCATATTCTCCA } \\
(4431-49)\end{array}$ & $2,3,4 a, 4 b$ & 980 \\
\hline $\mathrm{C}$ & $\begin{array}{l}\text { 5'-CAGAAGGGCTGAGTGACCT } \\
(4461-79)\end{array}$ & $\begin{array}{l}\text { 5'-CAGGTGCTAGCAAGATGAG } \\
(4713-31)\end{array}$ & 5 & 294 \\
\hline D & $\begin{array}{c}\text { 5'-CTGGCTTCCTCTCAGGTCC } \\
(4729-47)\end{array}$ & $\begin{array}{c}\text { 5'-ACAGAGACTCACAGGACCA } \\
(5526-44)\end{array}$ & $6,7,8$ & 839 \\
\hline $\mathbf{E}$ & $\begin{array}{c}\text { 5'-AAGGCCTCAACTGGATTCT } \\
(5952-70)\end{array}$ & $\begin{array}{c}\text { 5'-GAGAGGGTTAAAGTGCTGC } \\
(6985-7003)\end{array}$ & 9,10 & 1075 \\
\hline
\end{tabular}

To amplify each fragment, two oligonucleotide primers were used: an upstream primer with the sequence derived from the sense strand and a downstream primer with the sequence derived from the antisense strand. Numbers in parenthesis indicate location of the primer in the human GLUT-4 gene sequence. Since each upstream primer at its 5 ' end contained a 23-bp-long T7 phage promoter sequence (TAATACGACTCACTATAGGGAGA) to facilitate direct sequence analysis, the size of the individual PCR fragment was calculated after the addition of $23 \mathrm{bp}$. The nucleotide positions of the individual exons in the GLUT-4 gene sequence are as follows: exons $1 \rightarrow 2225-2257 ; 2 \rightarrow 3535-3651 ; 3 \rightarrow$ $3763-3935 ; 4 \mathrm{a} \rightarrow 4028-4152 ; 4 \mathrm{~b} \rightarrow 4276-4379 ; 5 \rightarrow 4507-4669 ; 6 \rightarrow 4775-4962 ; 7 \rightarrow 5125-5229 ; 8 \rightarrow 5378-5479 ; 9 \rightarrow 5995-6198 ;$ and $10 \rightarrow$ 6716-6919.

The downstream primers were designed to recognize only the normal (A) or mutant $\left(A^{\prime}\right)$ sequences by modifying the $3^{\prime}$ nucleotides of $A^{\prime}$ to correspond to the detected point mutation. Primer sets $A$ and $A^{\prime}$ directed amplification of a 194-base pair (bp) GLUT-4 allele-specific fragment. Primer set A only amplifies PCR fragments from alleles with normal sequences corresponding to the regions of the primers, and set $A^{\prime}$ amplifies PCR fragments only from alleles with mutations corresponding to the $3^{\prime}$ nucleotides of the downstream primer. The PCR was carried out according to standard conditions as described earlier at an annealing temperature of $50^{\circ} \mathrm{C}$ for $2 \mathrm{~min}$. As an internal positive control, all reaction mixtures contained an additional primer set (5'-12537 ACTCACCCAGGACGTGTCC ${ }^{12555}-3^{\prime} ; \quad 5^{\prime}-{ }^{13044}$ GAACGATCTCTGAACTCCA ${ }^{13026}-3^{\prime}$ ) for exon 22 of the insulin receptor. This primer set directs amplification of a 507-bp fragment.

\section{Results}

To elucidate whether structural defects in the insulin receptor and/or insulin-responsive glucose transporter could be a primary cause of insulin resistance in NIDDM, we have sequenced the entire coding region of the GLUT-4 gene and exons $16-22$ of the insulin receptor gene from white blood cell-derived DNA from six NIDDM patients.

Insulin receptor gene. Using genomic DNA as a template and oligonucleotides complementary to introns flanking each of the exons (23), we used PCR catalyzed by Taq DNA polymerase to amplify exons 16-22 of the insulin receptor gene. These exons encode the entire cytoplasmic domain of the receptor (18). The nucleotide sequence of the amplified DNA was then determined directly from the PCR mixture as described in the Methods section. When the sequences of exons 16-22 from the six NIDDM subjects were compared to the previously published normal insulin receptor gene sequence (18), no difference in the predicted amino acid sequence was observed. At nucleotide position 3045 (corresponding to the third nucleotide of codon 972 , according to the numbering by Ullrich et al. [28]), one patient was heterozygous for a silent polymorphism. Codon 972 was TAC and TAT (both Tyr) and, thus, this polymorphism did not change the amino acid sequence (data not shown).

GLUT-4 gene. The human GLUT-4 gene has been isolated and completely characterized by Bell et al. (13). The gene spans a region of $8,000 \mathrm{bp}$ on the short arm of chromosome 17 and is composed of 11 exons and 10 introns (13). Using the known sequence of the GLUT-4 gene as a guide, we selected five pairs of primers (Table II) to amplify 224-, 980-, 294-, 839-, and 1,075 -bp segments that include all 11 exons together with their adjacent splice acceptor and donor sites. Using genomic DNA as a template, the DNA amplification observed with these five primer pairs is very specific and analysis of the amplified DNA

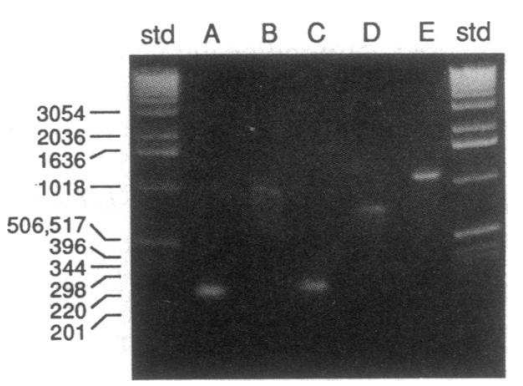

Figure 1. Amplification of the five fragments containing the 11 exons of the GLUT-4 gene by the PCR. Photograph of the ethidium bromidestained agarose gel of the PCR products is shown. The amplified fragments (A-E) are run in each lane as indicated. Fragments A, B, $C, D$, and $E$ contain exon 1; exons 2, 3, 4a and 4b; exon 5; exons 6-8; and exons 9 and 10, respectively. Lanes marked std. contain DNA standards. $5 \mu$ l of each PCR reaction was separated by electrophoresis on $1.5 \%$ agarose gel in Tris-acetate buffer. The DNA standard used a $1 \mathrm{~kb}$ DNA ladder from Bethesda Research Laboratories. 

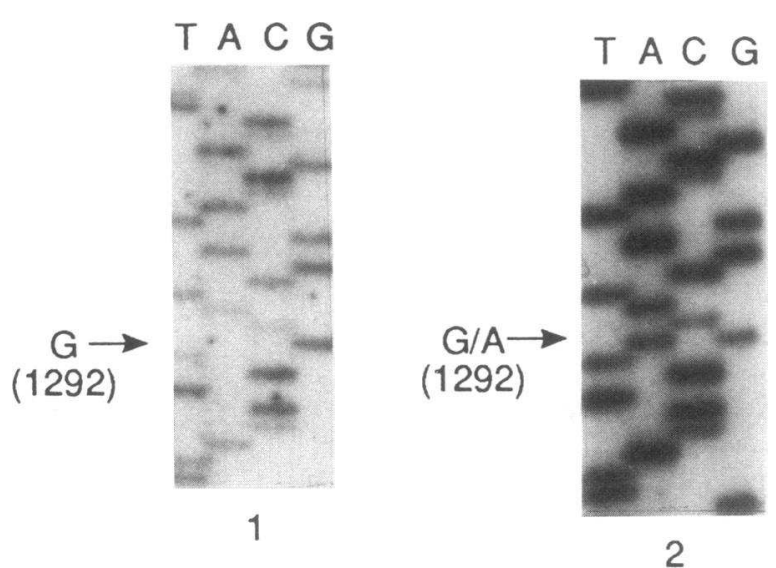

Figure 2. Partial nucleotide sequences of sense strand of GLUT-4 exon 9 from one of the six NIDDM subjects, compared to control. There are two bands ( $G$ and $A$ ) at nucleotide position 1292 (lane 2) in NIDDM patient 4 instead of just $\mathrm{G}$ as in the normal subject (lane 1 ).

by gel electrophoresis indicated that little nonspecific priming occurred (Fig. 1). The nucleotide sequences of the five PCRamplified fragments were determined as described in the Methods section. In five of the patients the predicted amino acid sequence was identical to the published normal sequence (29). The other subject (no. 4, Table I) was heterozygous for a substitution in the GLUT-4 sequence. This patient (no. 4) displays both $A$ and $G$ at nucleotide position 1292 (Fig. 2), corresponding to codon 383 in exon 9. This leads to an isoleucine (ATC) for valine (GTC) substitution in the fifth extracellular loop of the GLUT-4 protein (Fig. 3). This sequence difference was confirmed on three separate sequencing gels derived from three separate PCR amplifications. At nucleotide position 535 (corresponding to the third nucleotide of codon 130 [29]), two patients were heterozygous and one subject was homozygous for a silent nucleotide polymorphism. Codon 130 was AAC and AAT (both Asn) and thus, this polymorphism did not change the amino acid sequence (data not shown).

The valine $\rightarrow$ isoleucine substitution is conservative and Table III, which shows the sequence of GLUT-1, $-2,-3$, and -5 at codon 383, reveals leucine at position 383 in GLUT-1 and isoleucine in GLUT-5. To further assess the potential significance of mutation in NIDDM, we analyzed DNA from 24 additional NIDDM patients and 30 nondiabetic subjects for the presence of this substitution by allele-specific PCR amplification. This method involves the use of PCR oligonucleotide primer sets that amplify either the normal or mutant allele (30). As can be seen in Fig. 4, both the normal (A) and mutant ( $\left.A^{\prime}\right)$ allele-specific primer sets amplify a GLUT-4 DNA fragment of $194 \mathrm{bp}$ (lanes 1 and 2) from the genomic DNA of the patient (no. 4) who was heterozygous for the $\mathrm{Val}^{383} \rightarrow \mathrm{Ile}^{383}$ mutation. In the 30 control and 24 additional NIDDM subjects, PCR amplification of the 194-bp fragment occurred only with the normal allele primer set (A); lanes 3 and 4 show the results in representative subjects. The primer set for insulin receptor exon 22 gave rise to a 507-bp fragment in all samples, demonstrating that the absence of mutant GLUT-4 fragments was not due to a failure of the PCR.

\section{Discussion}

In patients with established NIDDM a variety of characteristic metabolic defects exist. Among these are insulin resistance, increased hepatic glucose production, and impaired pancreatic $\beta$ cell function (1). The disease is clearly heterogeneous, and it remains unproven which of these defects is primary. However, a number of studies have examined "prediabetic" individuals from high-risk populations and have found that insulin resistance can be demonstrated before the development of hyperglycemia and in the absence of the other metabolic defects $(2,3$, 31-33). These studies include first-degree relatives of NIDDM subjects (31), identical twins of NIDDM subjects (32), and subjects from ethnic groups at high risk for NIDDM (33), such as Pima Indians $(2,3)$. In the later population group, studies have shown that insulin resistance is inherited and predates the onset of hyperglycemia. The above-mentioned studies, as well as others (34), establish the strong genetic contribution to the development of NIDDM as well as the importance of insulin resistance.

In the current studies, we have focused our attention on the insulin receptor gene and the gene for the insulin-sensitive glucose transporter (GLUT-4) as candidate genes. The results represent the first sequence data available in NIDDM of the GLUT-4 gene and, except for single case studies (35-37), of the insulin receptor gene.

Insulin receptor. Insulin binding to the $\alpha$-subunit triggers activation of the tyrosine autophosphorylation/kinase activity of the cytoplasmic domain of the $\beta$ subunit which is felt to be essential for many, if not all, of insulin's bioeffects $(38,39)$. A modest decrease in receptor number exists in various tissues

Table III. Comparison of Partial Amino Acid Sequences between GLUT-4 of NIDDM Subjects and Different Human Facilitative Glucose Transporters

\begin{tabular}{cccccccc}
\hline $\begin{array}{c}\text { Subject } \\
\text { No. }\end{array}$ & $\begin{array}{c}\text { Amino acid } \\
\text { codon No. }\end{array}$ & GLUT-1 & GLUT-2 & GLUT-3 & GLUT-4 & GLUT-5 & $\begin{array}{c}\text { GLUT-4 from } \\
\text { NIDDM subject }\end{array}$ \\
\hline 4 & 383 & TyrLeuSer & TyrValSer & PheValCys & TyrValSer & TyrlleSer & $\begin{array}{c}\text { TyrValSer } \\
\text { TyrlleSer }\end{array}$ \\
\hline
\end{tabular}

Amino acid number is according to human GLUT-4 as described by Fukumoto et al. (29) and indicate the position of the amino acid (underlined) substituted. 


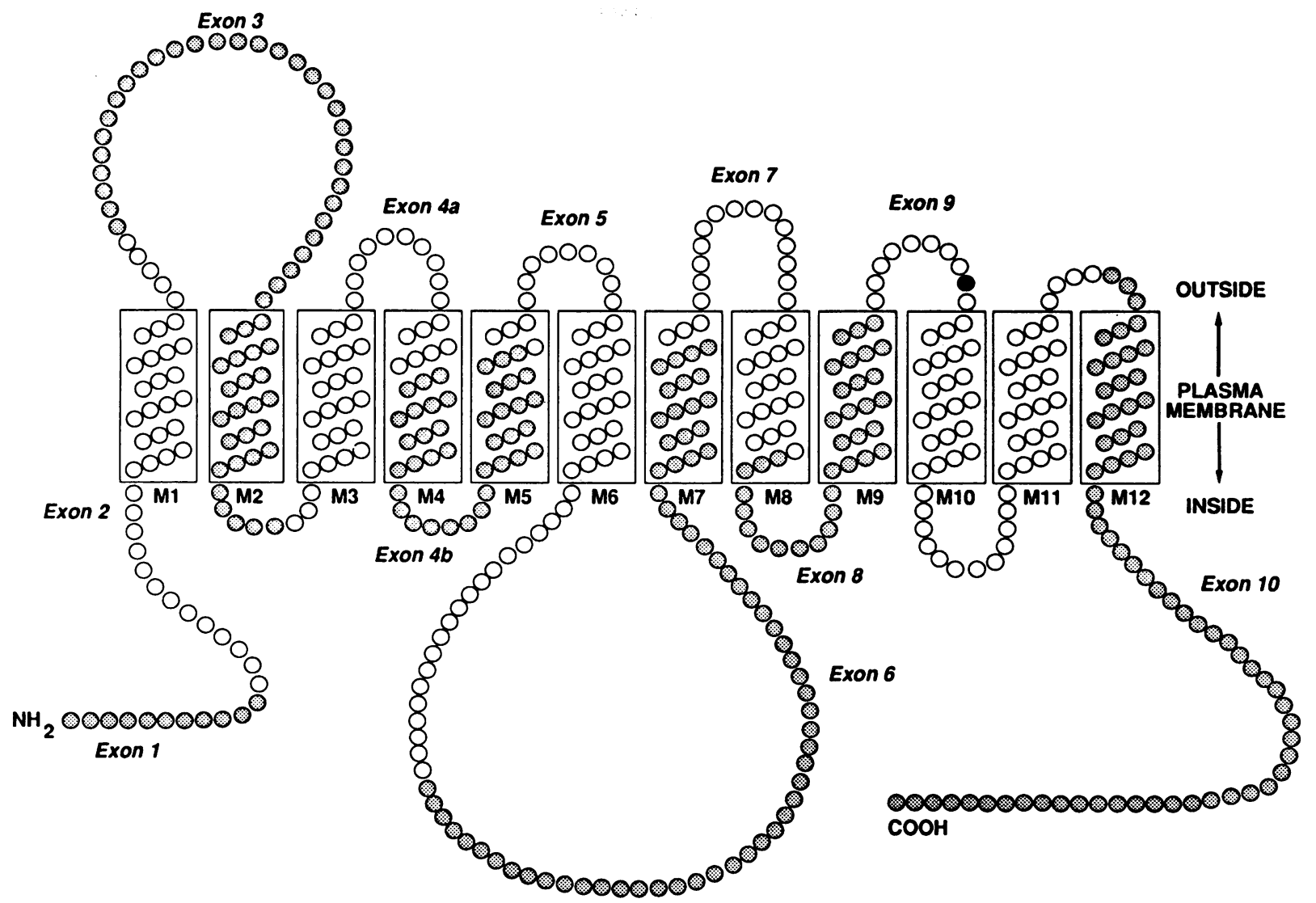

Figure 3. Modified model for the exon-intron organization of the insulin-sensitive human glucose transporter (GLUT-4) gene. Adapted from the model originally proposed for the ancestral facilitative glucose transporter gene by Bell et al. (13). The amino acids encoded by each of the 11 exons in the GLUT-4 gene are indicated by circles. 12 putative membrane-spanning domains are numbered M1-M12 and are shown as rectangles. A black circle indicates the position of the amino acid in GLUT-4 (383 according to numbering by Fukumoto et al. [29]), where the NIDDM subject was heterozygous for a conservative amino acid replacement.

from NIDDM subjects, but no alterations in the function of the $\alpha$ subunits with respect to binding affinity or specificity have been described (1). On the other hand, studies have consistently shown a decrease in the receptor kinase activity in NIDDM patients (7-10). Although these kinase defects are reversible with weight reduction (40) and do not exist in fibroblasts cultured from NIDDM patients (41), there could be a genetic alteration in the insulin receptor rendering it susceptable to a functionally adverse post-translational change.

Since the binding functions of the insulin receptor are preserved in NIDDM, whereas kinase activity and signaling are impaired, we restricted our studies to an analysis of the nucleotide sequence of exons 16-22 of the insulin receptor gene. These exons encode the entire cytoplasmic domain of the receptor protein including the kinase domain and other putative signaling elements (18).

In all six patients, the sequence of the insulin receptor cytoplasmic domain was entirely normal. Thus, no evidence for a genetic alteration leading to a change in the primary structure of the insulin receptor was found. These findings, coupled with a recent report that the full-length insulin receptor sequence was normal in an NIDDM patient (35), lead to the conclusion that variations in the coding sequence of the insulin receptor gene do not underlie the insulin resistance in the great majority of NIDDM patients. These results are also consistent with two recent reports demonstrating a normal insulin receptor sequence in two diabetic Pima Indians $(36,37)$. It should be pointed out that our results for both the insulin receptor and GLUT-4 genes relate only to alterations in the coding sequences; the possibility of regulatory defects in the flanking regions or deletion of an entire allele are not elucidated by our studies.

Although our studies demonstrate that most NIDDM patients have a normal insulin receptor sequence, they do not exclude the possibility that a small subset of patients with the NIDDM phenotype have mutations in the insulin receptor gene as a primary cause of their insulin resistance. Indeed, it is quite likely that this is the case, although this probably accounts for only a very small percentage of NIDDM patients. Thus, most patients with genetic forms of extreme insulin resistance (type A insulin resistance, leprechaunism, Rabson Mendenhall syndrome, etc.) are homozygotes or compound heterozygotes for insulin receptor gene mutations. However, many family members of these patients are simple heterozygotes, and 


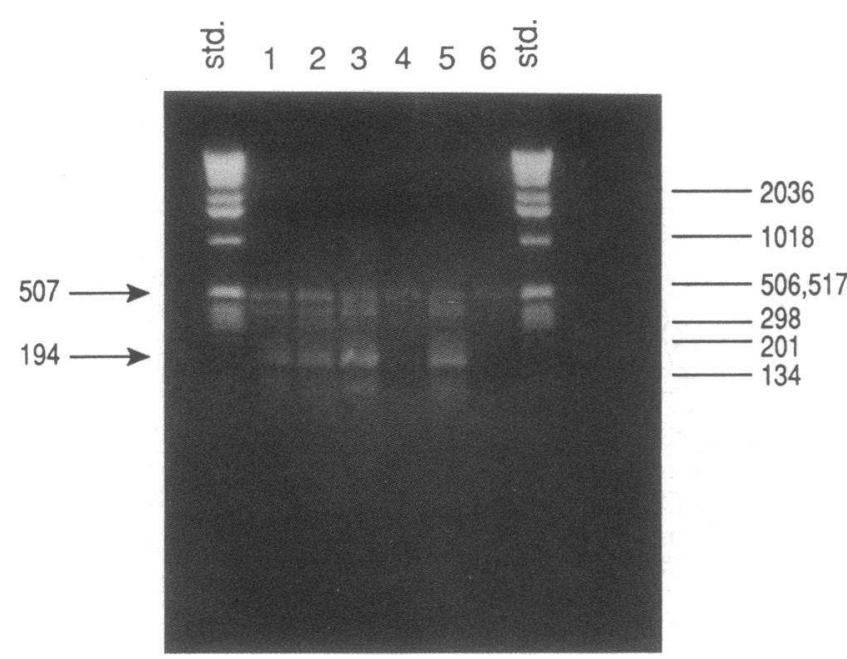

Figure 4. Identification of normal and mutant GLUT-4 gene alleles in NIDDM and normal subjects by the allele-specific PCR. Lanes $l$ and 2 represent results in the patient heterozygous for the mutation, $\mathrm{Val}^{383}$ $\rightarrow \mathrm{Ile}^{383}$, and lanes 3 and 4 and 5 and 6 show representative results from 24 additional NIDDM patients and 30 nondiabetic subjects. As an internal positive control, all reaction mixtures contained an additional primer set for the insulin receptor exon 22 that directed the amplification of a 507-bp fragment. Genomic DNA was isolated from the peripheral blood of normal or NIDDM subjects and PCR was performed as described in Methods using either the normal (A) (lanes 1,3 , and 5) or mutant $\left(\mathrm{A}^{\prime}\right)$ (lanes 2,4 , and 6) allele-specific primer sets. Both primer sets directed the amplification of a 194-bp GLUT-4 allele-specific fragment and the mutant $\left(\mathrm{A}^{\prime}\right)$ primer set is designed to detect the Ile $\mathrm{e}^{383}$ variant.

in some cases the amino acid substitutions behave as dominant negative mutations producing clinically significant insulin resistance and sometimes diabetes. The phenotype of these heterozygous family members is indistinguishable from NIDDM, particularly when the diabetes is discovered in later years. Possibly, mutations such as these, when coupled with other acquired abnormalities, such as obesity or $\beta$ cell dysfunction, produce the NIDDM syndrome and these kinds of heterozygous patients comprise the minimal estimate of the proportion of the NIDDM population associated with genetic mutations in the insulin receptor gene.

Insulin-sensitive glucose transporter (GLUT-4). At least five human glucose transporter species exist, displaying tissue specific distribution. An insulin-regulatable glucose transporter (GLUT-4) is uniquely expressed in muscle and adipose tissue and accounts for the majority of insulin-stimulated glucose transport $(13,14)$. Evidence exists to indicate that under most physiologic circumstances the glucose transport step is rate-limiting for overall in vivo glucose uptake (42). Consequently, defects in glucose transport could be mechanistically important to the in vivo insulin resistance in NIDDM. Indeed, decreased rates of glucose transport have been widely reported in adipocytes isolated from NIDDM subjects (43). Most likely, this is due to a reduced number of adipocyte GLUT-4 proteins as well as decreased intrinsic activity of the transporters (4). Skeletal muscle is responsible for $80-90 \%$ of insulin-stimulated glucose uptake in vivo, and decreased in vitro glucose transport has been reported in skeletal muscle from NIDDM subjects (44). These findings indicate that impaired glucose transport is an important factor in the insulin resistance of NIDDM. However, in skeletal muscle, total cellular GLUT-4 levels (15), as well as GLUT-4 mRNA (15) are normal in NIDDM. This indicates that the decreased skeletal muscle glucose transport in NIDDM is due to impaired recruitment (translocation) of GLUT-4 transporters to the cell surface, a decrease in GLUT-4 intrinsic activity, or both. Given these findings plus the genetic contribution to NIDDM, a primary defect in GLUT-4 structure seemed possible.

To assess this hypothesis, we have used PCR and direct sequencing to amplify and sequence all 11 GLUT-4 exons (13) from genomic DNA derived from six NIDDM subjects. Our results show that the GLUT-4 gene sequence was entirely normal in five of the six patients. One subject (no. 4) was heterozygous for an A for $\mathrm{G}$ mutation at nucleotide position 1292 leading to an isoleucine for valine substitution at codon 383 which is in the fifth extracellular loop of the GLUT-4 protein (Fig. 3). However, this is a structurally conservative substitution and among the five human glucose transporter species, two (GLUT-1 and GLUT-5) already contain leucine (GLUT-1) and isoleucine (GLUT-5) rather than valine at this position.

Since functional studies of transfected GLUT -4 cDNAs can be problematic (44), we elected to pursue whether this substitutions were significant in the etiology of NIDDM, by analyzing DNA from an additional 24 NIDDM patients and 30 nondiabetic subjects. Allele-specific PCR amplification was used to detect the presence of this substitution, and these additional subjects showed only wild-type sequence at this position. Thus, of the 60 NIDDM alleles analyzed, the frequency of the polymorphism identified was only one in 60 and it was not detected in 30 nondiabetic subjects. From this, we conclude that this specific genetic variant is uncommon and could only represent a very small subset of the NIDDM population. Given the low frequency of this variant in the NIDDM group, studies in a greatly expanded number of normals would be necessary to determine whether its frequency is lower in normal versus NIDDM subjects.

The simplest interpretation of our data is that substitutions in GLUT-4 are unusual in NIDDM and, therefore, do not contribute to this disease in the great majority of NIDDM patients. However, we should also point out that although our results provide evidence that no single mutation in the GLUT4 gene exists in a high proportion of NIDDM subjects, we did identify one substitution among our six subjects. This raises the theoretical possibility that GLUT-4 gene mutations exist in a small, but significant, subgroup of NIDDM patients, but that no single mutation will be common. Insofar as any GLUT-4 substitution is functionally significant, it could have importance to the NIDDM state.

If inherited structural defects in the insulin receptor and GLUT-4 genes are not the primary cause of cellular insulin resistance in most NIDDM subjects, then what defects might be involved? Insulin action is obviously a complex process involving multiple sequential steps. Our data would indicate that, if a common genetic defect in the insulin action cascade exists, it is located at a step(s) between the insulin receptor and GLUT-4. Since the total amount of skeletal muscle GLUT-4 protein is normal in NIDDM (15), it is reasonable to propose 
that a defect in recruitment of transporters to the cell surface exists. This implies a postreceptor signaling abnormality in this aspect of insulin action. Since not all aspects of insulin action are equally resistant in NIDDM, it is possible that such a defect lies in one or more proteins involved in the arm of postreceptor insulin signaling related to glucose metabolism. Perhaps NIDDM is multigenic and subgroups of patients will display genetic defects in different proteins, in aggregate accounting for the insulin resistance in NIDDM, consistent with the heterogeneous nature of this disease.

Note added in proof. Based on preliminary data reported in abstract form (1991. Diabetes. 40:158A), a valine for methionine mutation at GLUT-4 position 126 was initially identified in one of our patients. However, subsequent experiments showed the sequence to be normal in this patient.

\section{Acknowledgments}

We thank Dr. Graeme Bell and Dr. S. Seino, Howard Hughes Medical Institute, University of Chicago, for sharing their results with PCR amplification of the GLUT-4 gene and for providing us with human GLUT -4 gene sequences before publication. We also thank Mrs. Elizabeth Martinez and Cleon Tate for their expert assistance in the preparation of this manuscript.

This work was supported by National Institutes of Health grant DK-33649 and the Veterans Administration Medical Center Research Service.

\section{References}

1. Olefsky, J. M. 1989. Pathogenesis of non-insulin-dependent diabetes (type II). In Endocrinology. Second edition. L. J. DeGroot, G. M. Besser, G. F. Cahill, J. C. Marshall, D. H. Nelson, W. D. Odell, J. T. Potts, Jr., A. H. Rubenstein, and E. Steinberger, editors. W. B. Saunders, Co., Philadelphia. 1369-1388.

2. Warram, J. H., B. C. Martin, A. S. Krolewski, J. S. Soeldner, and C. R. Kahn. 1990. Slow glucose removal rate and hyperinsulinemia precede the development of type II diabetes in offspring with diabetic parents. Ann. Intern. Med. 113:909-915.

3. Saad, M. F., W. C. Knowler, D. J. Pettitt, R. G. Nelson, D. M. Mott, and P. H. Bennett. 1988. The natural history of impaired glucose tolerance in the Pima Indians. N. Engl. J. Med. 319:1500-1506.

4. Olefsky, J. M., W. T. Garvey, R. R. Henry, D. Brillon, S. Matthaei, and G. R. Freidenberg. 1988. Cellular mechanisms of insulin resistance in non-insulin-dependent (type II) diabetes. Am. J. Med. 85:86-105.

5. Kolterman, O. G., G. R. Gray, J. Griffin, P. Burnstein, J. Insel, J. Scarlett, and J. M. Olefsky. 1981. Receptor and post-receptor defects contribute to the insulin resistance in non-insulin-dependent diabetes mellitus. J. Clin. Invest. 68:957-969.

6. Truglia, J. A., J. N. Livingston, and D. H. Lockwood. 1985. Insulin resistance: receptor and post-binding defects in human obesity and non-insulin-dependent diabetes mellitus. Am. J. Med. 979(Suppl. 2B):13-21.

7. Freidenberg, G. R., R. R. Henry, H. H. Klein, D. R. Reichart, and J. M. Olefsky. 1987. Decreased kinase activity of insulin receptors from adipocytes of non-insulin-dependent diabetic subjects. J. Clin. Invest. 79:240-250.

8. Sinha, M. K., W. J. Pories, E. G. Flickinger, D. Meelheim, and J. F. Caro. 1987. Insulin-receptor kinase activity of adipose tissue from morbidly obese humans with and without non-insulin-dependent diabetes mellitus. Diabetes. 36:620-625.

9. Caro, J. F., O. Ittoop, W. J. Pories, D. Meelheim, E. G. Flickinger, F. Thomas, M. Jenquin, J. F. Silverman, P. G. Khazanie, and M. K. Sinha. 1986 Studies on the mechanism of insulin resistance in the liver from humans with non-insulin-dependent diabetes. J. Clin. Invest. 78:249-58.

10. Caro, J. F., M. K. Sinha, S. M. Raju, O. Ittoop, W. J. Pories, E. G. Flickinger, D. Meelheim, and G. L. Dohm. 1987. Insulin receptor kinase in human skeletal muscle from obese subjects with and without non-insulin-dependent diabetes. J. Clin. Invest. 79:1330-1337.

11. Comi, R. J., G. Grunberger, and P. Gorden. 1987. Relationship of insulin binding and insulin stimulated tyrosine kinase activity is altered in type II diabetes. J. Clin. Invest. 79:453-462.

12. Dohm, G. L., E. B. Tapscott, W. J. Pories, D. J. Dabbs, E. G. Flickinger, D. Meelheim, T. Fushiki, S. M. Atkinson, C. W. Elton, and J. F. Caro. 1988. An in vitro human muscle preparation suitable for metabolic studies: decreased insulin stimulation of glucose transport in muscle from morbidly obese and diabetic subjects. J. Clin. Invest. 82:486-494.

13. Bell, G. I., T. Kayano, J. B. Buse, C. F. Burant, J. Takeda, D. Lin, H. Fukumoto, and S. Seino. 1990. Molecular biology of mammalian glucose transporters. Diabetes Care. 13:198-208.

14. James, D. E., M. Strube, and M. Mueckler. 1989. Molecular cloning and characterization of an insulin-regulatable glucose transporter. Nature (Lond.). 338:83-87.

15. Pedersen, O., J. F. Bak, P. H. Andersen, S. Lund, D. E. Moller, J. S. Flier, and B. B. Kahn. 1990. Evidence against altered expression of GLUT-1 or GLUT4 in skeletal muscle of patients with obesity or NIDDM. Diabetes. 39:865-870.

16. Newman, B., J. V. Selby, M. L. King, C. Slemenda, R. Fabsitz, and G. D. Friedman. 1987. Concordance for type 2 (non-insulin-dependent) diabetes mellitus in male twins. Diabetologia. 30:763-769.

17. Barnett, A. H., C. Eff, R. D. G. Leslie, and D. A. Pyke. 1981. Diabetes in identical twins: a study of 200 pairs. Diabetologia. 20:87-93.

18. Seino, S., M. Seino, S. Nishi, and G. I. Bell. 1989. Structure of the human insulin receptor gene and characterization of its promoter. Proc. Natl. Acad. Sci. USA. 86:114-118.

19. Olefsky, J. M., O. G. Kolterman, and J. A. Scarlett. 1982. Insulin action and resistance in obesity and non-insulin-dependent type II diabetes mellitus. Am. J. Physiol. 243:E15-E30.

20. Sinha, M. K., L. G. Taylor, W. J. Pories, E. G. Flickinger, D. Meelheim, S. Atkinson, N. S. Sehgal, and J. F. Caro. 1987. Long-term effect of insulin on glucose transport and insulin binding in cultured adipocytes from normal and obese humans with and without non-insulin-dependent diabetes. J. Clin. Invest. 80:1073-1081.

21. Maniatis, T., E. F. Fritsch, and J. Sambrook, editors. 1982. Molecular Cloning: A Laboratory Manual. Cold Spring Harbor Laboratory, Cold Spring Harbor, NY.

22. Saiki, R. K., D. H. Gelfand, S. Stoffel, S. J. Scharf, R. Higuchi, G. T. Horn, K. B. Mullis, and H. A. Erlich. 1988. Primer-directed enzymatic amplification of DNA with a thermostable DNA polymerase. Science (Wash. DC). 239:487-491.

23. Seino, S., M. Seino, and G. I. Bell. 1990. Insulin receptor gene: partial sequence and amplification of exons by polymerase chain reaction. Diabetes. 39:123-128.

24. Stoflet, E. S., D. D. Koeberl, G. Sarkar, and S. S. Sommer. 1988. Genomic amplification with transcript sequencing. Science (Wash. DC). 239:491-494.

25. Gyllensten, U. 1989. Direct Sequencing of In Vitro Amplified DNA in PCR Technology-Principles and applications for DNA Amplification. E. A. Erlich, editor. Stockton Press, New York. 45-70.

26. Kadowaki, T., H. Kadowaki, and S. I. Taylor. 1990. A nonsense mutation causing decreased levels of insulin receptor mRNA: detection by a simplified technique for direct sequencing of genomic DNA amplified by the polymerase chain reaction. Proc. Natl. Acad. Sci. USA. 87:658-662.

27. Sarkar, G., J. Cassady, C. D. K. Bottema, and S. S. Sommer. 1990. Characterization of polymerase chain reaction amplification of specific alleles. Anal. Biochem. 186:64-68.

28. Ullrich, A., J. R. Bell, E. Y. Chen, R. Herrera, L. M. Petruzzelli, T. J. Dull, A. Gray, L. Coussens, Y. C. Liao, M. Tsubokawa, et al. 1985. Human insulin receptor and its relationship to the tyrosine kinase family of oncogenes. Nature (Lond.). 313:756-761.

29. Fukumoto, H., T. Kayano, J. B. Buse, Y. Edwards, P. F. Pilch, G. I. Bell, and S. Seino. 1989. Cloning and characterization of the major insulin-responsive glucose transporter expressed in human skeletal muscle and other insulin-responsive tissues. J. Biol. Chem. 264:7776-7779.

30. Wu, D. Y., L. Ugozzoli, B. K. Pal and R. B. Wallace. 1989. Allele-specific enzymatic amplification of $\beta$-globin genomic DNA for diagnosis of sickle cell anemia. Proc. Natl. Acad. Sci. USA. 86:2757-2760.

31. Eriksson, J: A. Franssila-Kallunki, A. Ekstrand, C. Saloranta, E. Widen, C. Schalin, and L. Groop. 1989. Early metabolic defects in persons at increased risk for non-insulin dependent diabetes mellitus. N. Engl. J. Med. 321:337-343.

32. Serjeantson, S. W., and P. Zimmet. 1989. Genetics of NIDDM-pilgrim's progress. In Miles Monographs in Diabetes Mellitus. Frontiers of Diabetes Research: Current Trends in Non-insulin-dependent Diabetes Mellitus. K. G. M. M. Alberti and R. S. Mazze, editors. Excerpta Medica, Lawrenceville, NJ. 21-35.

33. Keen, H. 1989. Diabetes epidemiology, a frontiersmen's tool. In Miles Monographs in Diabetes Mellitus. Frontiers of Diabetes Research: Current Trends in Non-insulin-dependent Diabetes Mellitus. K. G. M. M. Alberti and R. S. Mazze, editors. Excerpta Medica, Lawrenceville, NJ. 3-20.

34. O'Rahilly, S., R. S. Spivey, R. R. Holman, Z. Nugent, A. Clark, and R. C. 
Turner. 1987. Type II diabetes of early onset: a distinct clinical and genetic syndrome. Br. Med. J. 294:923-928.

35. Kusari, J., J. M. Olefsky, C. Strahl, and D. A. McClain. 1991. Insulin receptor cDNA sequence in NIDDM patient homozygous for insulin-receptor gene RFLP. Diabetes. 40:249-254.

36. Moller, D. E., A. Yokota, and J. S. Flier. 1989. Normal insulin-receptor cDNA sequence in Pima Indians with NIDDM. Diabetes. 38:1496-1500.

37. Cama, A., A. P. Patterson, T. Kadowaki, H. Kadowaki, G. Siegel, D. D'Ambrosio, S. Lillioja, J. Roth, and S. I. Taylor. 1990. The amino acid sequence of the insulin receptor is normal in an insulin-resistant Pima Indian. J. Clin. Endocrinol. Metab. 70:1155-1161.

38. Kahn, C. R., and M. F. White. 1988. The insulin receptor and the molecular mechanism of insulin action. J. Clin. Invest. 82:1151-1156.

39. Olefsky, J. M. 1990. The insulin receptor: a multifunctional protein. Diabetes. 39:1009-1016.
40. Henry, R. R., P. Wallace, and J. M. Olefsky. 1986. Effects of weight loss on mechanisms of hyperglycemia in obese non-insulin-dependent diabetes mellitus. Diabetes. 35:990-998.

41. Freidenberg, G. R., D. Reichart, and J. M. Olefsky. 1990. Insulin receptor kinase activity is not reduced in fibroblasts from subjects with non-insulin-dependent diabetes mellitus (NIDDM). Clin. Res. 38:119A. (Abstr.)

42. Kasanicki, M. A., and P. F. Pilch. 1990. Regulation of glucose-transporter function. Diabetes Care 13:219-227.

43. Ciaraldi, T. P., O. G. Kolterman, J. A. Scarlett, M. Kao, and J. M. Olefsky. 1982. Role of glucose transport in the post-receptor defect of non-insulin dependent diabetes mellitus. Diabetes. 31:1016-1022.

44. Woon, C. W., S. A. Harrison, J. M. Buxton, S. Perregaux, and M. P. Czech. 1991. The $\mathrm{NH}_{2}$-terminal domain of the human GLUT 1 confers a high level expression of glucose transporters in chinese hamster ovary fibroblasts. $J$. Cell. Biochem. Suppl. 15B:64. (Abstr.) 